\title{
POLITIK IDENTITAS DALAM SEJARAH PEMBENTUKAN NEGARA ISRAEL
}

\author{
Elpeni Fitrah ${ }^{1}$
}

\begin{abstract}
This paper discusses how the political identity becomes a motive of Israel state formation. Identity politics is a part of cultural politics which consisted by race, religion, ethnic and culture. The Author identified identity politics as a concept or political movement which focusing into diversity. The main argument of this paper is Israel has succeed utilize its cultural identity narrative to unite the perception of the Jewish around the world to reproduce as a historical justification as well as the tools of politics for the sake of the embodiment of national ideals in establishing their own nation state.
\end{abstract}

Keywords: Identity Politics, Narrative, Perception, Israel

\section{Pendahuluan}

Tulisan ini berangkat dari pemahaman utama bahwa berdirinya suatu negara bangsa tidak bisa dilepaskan dari narasi identitas yang menyertainya. Dipandang dari sisi sejarah evolusi masyarakat, sebagaimana Hegel dan Karl Marx, evolusi sebuah kelompok masyarakat akan berujung pada keinginan untuk membentuk suatu kelompok masyarakat yang didasarkan pada ikatan-ikatan identitas yang paling dalam dan fundamental seperti budaya, etnis dan agama dan bahkan mereka siap menggunakan berbagai tindakan kekerasan untuk meraih politik identitas ini (Perwita, 2008).

Sebagai representasi dari politik identitas, dalam tulisan ini penulis mengkaji mengenai narasi identitas dibalik berdirinya negara Israel. Penulis mengajukan pembahasan mengenai topik ini karena sejak awal pembentukan Negara Israel, batas negara Israel beserta hak Israel untuk berdiri telah dipertentangkan oleh banyak pihak, terutama oleh negara Arab dan para pengungsi Palestina. Meski demikian, Israel sebagai satusatunya negara Yahudi di dunia tetap sukses mendeklarasikan kemerdekaannya pada tanggal 14 Mei 1948. Menurut penulis, berdirinya negara Israel sebagai rumah bagi kaum Yahudi diaspora adalah contoh bagaimana label identitas yang direproduksi dan dinarasikan terus-menerus turut berperan dalam pembentukan negara bangsa. Label identitas itu mengandung unsur-unsur ras, etnis, budaya dan agama. Salah satunya mengenai Palestina yang diklaim sebagai tanah pengharapan milik leluhur bangsa Yahudi.

Politik identitas merupakan sebuah

\footnotetext{
${ }^{1}$ Staf Pengajar pada Program Studi Hubungan Internasional, FISIP Universitas Jenderal Soedirman.
} 
wacana politik tentang kehidupan sehari-hari yang kategori utamanya adalah perbedaan, didalamnya terjadi permainan dan pergulatan identitas-identitas perbedaan. Jalan analisis Foucault, seperti aktor-aktor poststrukturalis kemudian postmodern lainnya menjadi suatu gerakan kritik terhadap apa saja melalui dekonstruksi, perbedaan dan wacana-wacana kecil (Abdillah, 2003, xiii). Oleh sebab itu penulis harus menyebut bahwa wacana postmodernisme dalam bahasan ini secara tidak langsung memposisikan diri sebagai kritik terhadap wacana besar modernitas, khususnya kedalam politik modern. Lebih khusus lagi sebenarnya adalah analisis terhadap wacana etnis dalam konteks politik, yang punya sejarah panjang dalam sejarah peradaban, politik khususnya.

Etnis memberikan banyak sumbangan terhadap munculnya konsep negara bangsa (nation state), yang dalam wacana sosial interaksi modern menjadi sebuah cara atau model pembacaan sosial yang dikotomis dan oposisional "kami/mereka". Pengaruhnya, dalam analisis penulis, terjadi perbedaan dalam hubungan sosial yang mengantarkan pada bentuk hubungan dengan warna-warni Chaos, kekerasan (violence), genocide, rasisme dan ironi kemanusiaan lainnya.

\section{Metodologi}

\section{Hermeneutika; Model Analisis \\ Intersubjektif Dalam Ilmu Sosial}

Hermeutika, menurut penulis, dapat direfleksikan dalam konteks fenomenologi sosial dan teori kritis. Ilmu-ilmu sosial mau menganalisis segala sesuatu yang ada di dalam dunia kehidupan, yakni segala obyek simbolik yang dihasilkan dalam percakapan serta tindakan. Di dalamnya terkandung pula ungkapan-ungkapan langsung, seperti pikiran, perasaan, serta keinginan. Kesemua itu dapat ditemukan dalam teks-teks kuno, tradisi, karya seni, teknik, barang-barang kebudayaan dan juga di dalam struktur yang bersifat stabil dan tertata, seperti sistem sosial, struktur, kepribadian, dan pranata-pranata (Hardiman, 2003, 63).

Obyek di dalam ilmu-ilmu sosial, menurut Willeam Dilthey hanya dapat diketahui secara reproduktif melalui empati. Hermeneutika memfokuskan studinya pada telaah atas teks, dan teks kini lebih dimengerti sebagai realitas sosial. Menurut Dilthey, peneliti teks haruslah mampu berempati secara psikologis ke dalam isi dari teks, serta pengarangnya. Artinya, pembaca harus mampu untuk mengalami kembali segala sesuatu yang telah dialami oleh penulis teks tersebut. Dengan demikian, hermeneutika adalah menafsirkan secara reproduktif, baik itu menafsirkan struktur psikologis sang pencipta teks, maupun struktur simbolik yang memungkinkan karya tersebut tercipta. Sebagaimana disebutkan dimuka, makna akan kita dapat pada pada tindakan, peristiwa, katakata, barang kebudayaan, dan dokumendokumen, yang kesemuanya hanya dapat diketahui dari dalam.

Dengan demikian, di dalam ilmu-ilmu 
sosial, seorang peneliti yang terus menerus bertindak sebagai seorang pengamat tidak akan dapat sungguh memahami makna di dalam dunia sosial. Maka, seorang peneliti sosial sebaiknya berempati terhadap realitas sosial yang akan ditelitinya tersebut. Realitas sosial tidak bisa dipandang melulu sebagai obyek, melainkan sebagai subyek yang setara. Pada titik inilah diperlukan paradigma komunikatif yang melihat peneliti maupun realitas sosial yang ditelitinya sebagai dua subyek yang setara, sehingga makna maupun kesalingpemahaman antara kedua belah pihak dapat dicapai.

Sebagaimana penjelasan diatas, sesuai konsepsi hermeneutika, maka penulis akan berdiri persis dimana objek sosial yang diteliti berada. Penulis seolah-olah sedang melakukan wawancara imajinatif dengan nara sumber pelaku sejarah dipandu oleh teks-teks yang beredar disekelilingnya. Laporan penelitian ini penulis tulis dengan model tulisan naratif, bercerita dan mengalir layaknya sungai yang bermuara pada pemahaman (understanding).

\section{Kerangka Konseptual}

\section{Teori Persepsi}

Persepsi adalah pandangan seseorang yang telah melalui tahapan melihat, merasa, memikirkan dan diolah oleh pengalaman dan teori yang diyakini. Menurut Stephene Robbins (2008), persepsi adalah sebuah proses ketika manusia mengorganisasikan dan menginterpretasikan kesan hasil pencitraan indrawi mereka dalam upaya memaknai dunia disekitarnya.

Perception is defined as the process by which people organize and interpret their sensory impressions in order to give meaning to the world around them. Perception is basically how each individual views the world around them. What one perceives can be very different from actually reality. The perception of one person will vary greatly from that of another person. Perception can have a huge impact on decision-making and on an organization's behavior in whole."

Robbins mengatakan bahwa dari hasil persepsi masyarakat terhadap realitas disekitarnya akan berpengaruh besar terhadap pembuatan keputusan sekaligus bentuk prilaku kelompok tersebut secara keseluruhan. Proses terbentuknya persepsi banyak dipengaruhi oleh beragam referensi.. Oleh sebab itulah, biasanya cepat atau lambat mereka akan mencermati kelompok referensi terdekat dengannya. Bisa jadi persepsi tersebut dibangun berdasarkan aspek kultural yang melingkupi lingkungan dan sejarah mereka, misalnya berdasarkan etnisitas, budaya dan agama. Bangunan persepsi inilah yang kelak memunculkan subyektifitas masyarakat dalam melihat kehidupan mereka. Bertrand Russell (2008) mengatakan bahwa masyarakat hanya ingin melihat apa yang mereka inginkan berdasarkan interaksinya dengan masyarakat lain juga pengalaman-pengalamannya. Aspek budaya berperan penting dalam menumbuhkan datadata yang berhubungan dengan perasaan." 
Menurut sejarah, persepsi menjadi salah satu faktor penyebab terjadinya konflik antar negara. Bertrand Russels menjelaskan kondisi ini sebagai berikut:

"These fine lines which allow the perception of entities and categories (and thereby giving order and meaning to the chaotic experiences of everyday life) are largely social in origin. They create the boundaries between what's mine and yours, between "us" and "them," what's sacred and profane, and what's "real" and "unreal."

Jadi dalam proses terbentuknya persepsi dan pengambilan keputusan, disamping berasal dari organ sensorik manusia yang diolah dalam otak juga berdasarkan faktor perorangan (personal factors) semacam tipe kepribadian, kedewasaan teori, status secara emosional dan pengalaman-pengalaman sosial. Artinya lingkungan sosial sebagian besar menentukan apa yang kita rasa (perceive) dan apa yang kita abaikan (ignore), tinggal dengan cara apa manusia memproses informasi tersebut secara teori. "Shaping perceptions is, as will be seen, the key to social power" ungkap Bertrand Russell.

Dengan pendekatan ini, kita akan lebih mudah memahami, memprediksikan sekaligus menjelaskan arti sikap dan tindakan sebuah kelompok masyarakat, pemikiran maupun motivasi terjadinya tindakan tersebut. Menurut penulis berdirinya negara Israel berkelindan dengan persepsi-persepsi. Persepsi direproduksi menjadi pembenaran historis sekaligus alat politik demi perwujudan cita-cita nasional. Berdirinya negara Israel menyita perhatian masyarakat internasional karena berdiri ditengah wilayah negara lain yang sedang berusaha mencapai kemerdekaannya, yaitu Palestina.

Kenapa harus Palestina (negara tujuan berdirinya Israel)? Jawabnya adalah suku bangsa Yahudi telah lama menginginkan berdirinya negara sendiri bagi kaumnya. Keputusan memilih Palestina direproduksi dari hasil persepsi bangsa Yahudi berdasarkan aspek sejarahnya. Aspek-aspek sejarah itu mengerucut pada bidang-bidang budaya yang (lebih) mengikat persamaan (identitas) diantara mereka berdasarkan etnis, budaya dan agama. Singkatnya, hasil reproduksi persepsi tersebut, sebagaimana penjelasan diatas, memunculkan beberapa unsur negatif yang mengganggu perdamaian dan keamanan. Bentuk instabilasasi perdamaian dan keamanan tersebut masih bisa kita rasakan detik ini, setidaknya dari sekian solusi damai belum ada yang benar-benar menghentikan konflik.

\section{Teori Narasi Identitas}

Istilah narasi pada dasarnya mengacu pada terminologi kesusastreraan. Narasi dipahami sebagai cerita (mite, legenda, cerita rakyat). Namun Roland Barthes (1987, 79) melihat bahwa tidak hanya cerita dalam artian fiksional saja yang memiliki atau mengandung struktur naratif (plot, sudut pandang, penokohan, dll). Lebih jauh naratif (baik dalam artian kata benda maupun kata sifat: narrative) hadir dalam berbagai varietas genre.

\section{"The narratives of the world}


are numberless. Narrative is first and foremost a prodigious variety of genres, themselves distributed amongst different substances - as though any material were fit to receive man's stories. Able to be carried by articulated language, spoken or written, fixed or moving images, gestures, and the ordered mixture of all these substances; narrative is present in myth, legend, fable, tale, novella, epic, history, tragedy, drama, comedy, mime, painting...stained glass windows, cinema, comics, news items, conversation. ...[N]arrative is present in every age, in every place, in every society; it begins with the very history of mankind and there nowhere is nor has been a people without narrative. [N] arrative is international, transhistorical, transcultural: it is simply there, like life itself."

Barthes secara tegas menyebutkan bahwa naratif dapat hadir tidak hanya dalam mite, legenda, novel, atau cerita apapun dalam artian fiksional, tetapi juga naratif muncul dalam sejarah, lukisan, gambar, percakapan, dll. Naratif hadir di setiap zaman, setiap tempat, dan masyarakat. bahkan secara radikal, Barthes mengklaim bahwa tidak ada apapun di luar narasi, sebagaimana kehidupan itu sediri.

Bila kita memperlakukan narasi sebagai sebuah wacana (narrative discourse), maka proses pelekatan narasi hingga menjadi sebuah mitos yang biasa disebut proses mitologisasi menjadi sangat kompleks. Namun jika proses tersebut kita sederhanakan, maka pelekatan narasi menjadi identitas diri tidak lepas dari sebuah reproduksi terus menerus oleh agen-agen kebudayaan. Sebuah cerita atau sejarah dikisahkan secara kontinyu dan turun temurun - baik melalui institusi kebudayaan maupun tidak - akan melekat menjadi identitas kolektif.

Menurut Ricouer sebuah kebudayaan haruslah memiliki narasai historisnya sendiri, sehingga kebudayaan tersebut dapat melihat masa depan dan apa yang harus dilakukan dimasa depan. Jika sebuah Kebudayaan tersebut tidak memiliki narasi untuk melewati gengerasi berikutnya maka narasi tersebut akan lenyap dan orang-orang pada gengerasi setelahnya akan hilang. $\quad \mathrm{N}$ arasi yang dibangun oleh suatu kebudayaan memiliki konsekuensi tertentu terhadap individu dalam kelompok tersebut. Narasi akan membentuk identitas individu yang dapat disebut sebagai identitasnya. Seperti yang diungkapkan oleh Ricoeur $(1985,147)$ :

"...narrative constructs the identity of the character, which can be called his or her identity, in constructing the story told. It is the identity of the story which makes the identity of the character"

\section{Giddens memperkuat argumentasi} Ricoeur dengan menyatakan bahwa identitas diri terbangun oleh kemampuan untuk melanggengkan narasi tentang diri, sehingga membangun suatu perasaan terus menerus tentang adanya kontinuitas biografis. Cerita 
identitas berusaha menjawab sejumlah pertanyaan kritis "apa yang harus dilakukan? Bagaimana bertindak? Dan ingin jadi siapa?" individu berusaha mengkostruksi suatu narasi identitas koheren dimana diri membentuk suatu lintasan perkambangan dari masa lalu sampai masa depan yang dapat diperkirakan.

Dalam konteks berdirinya negara Israel, kaum Yahudi membentuk persepsi kelompoknya secara teologis dan diperkuat dengan sebuah kesadaran kolektif akan penderitaan kelompok. Disini ada sekian banyak narasi yang menyatukan persepsi kolektif masyarakat Yahudi. namun dalam kajian ini penulis melihat dari narasi sudut pandang pembentukan kesadaran mental akan urgensi berdirinya sebuah nation atau state bangsa Yahudi itu sendiri. Narasi tersebut adalah teks-teks teologis (dalam hal ini Taurat) sebagai pendukung konseptual serta peristiwaperistiwa terdahulu, seperti ketertindasan etnis Yahudi di Jerman pada masa Adolf Hitler yang dikenal dengan tragedi Holocaust sebagai elemen penguatnya di wilayah praksis. Jadi identitas keyahudian, murni bukan dibentuk oleh ciri-ciri biologis atau sifat-sifat kultural tertentu, tapi ini lebih dikonstruksi oleh narasi yang dibangun melalui agen-agen kebudayaan. Penjelasan mengenai kedua narasi tersebut terhadap signifikansi berdirinya negara Israel. selanjutnya akan dijelaskan lebih dalam pada bagian selanjutnya tulisan ini.

\section{Pembahasan}

Narasi Identitas dibalik Berdirinya Negara

\section{Israel}

Identitas sebagaimana pemahaman kita terdahulu berkelindan dengan tradisi dan tradisi bukanlah sehimpun norma yang dapat dengan gampang ditunjuk, setidaknya demikian M. Arkoun sebagaimana ditulis oleh Robert D. Lee (2000, 34) dalam bukunya "Mencari Islam Autentik dari Nalar Puitis Iqbal hingga Nalar Kritis Arkoun".

Ibarat rambu, tradisi adalah tanda yang acuannya tak tentu, remang dan kabur. Makna dari tanda itu tergantung dari siapa yang menafsirkannya. Penafsiran ternyata bukan cuma soal pemahaman dan rumusan; tetapi juga seleksi dan penyisihan. Dalam kata-kata Michel Foucault, penafsiran adalah proses yang mesti dijelaskan "melalui apa, atau siapa, yang ia kecualikan atau tidak dibenarkan masuk". Lalu muncul pertanyaan ideologis, apakah setiap pencarian otensitas itu akan selalu berbarti "politik identitas" yang berakhir pada pertentangan secara antagonistik? Tentunya semua keragaman tafsir dari aneka latar belakang manusia akan membawa diskursus ini pada wilayah dialog melalui pengkajian yang bersifat kritis dan reflektif.

Berikut adalah Narasi Identitas yang direproduksi oleh bangsa Yahudi untuk mendirikan Negera Israel:

\section{Rasisme}

Beberapa faktor penguat bersatunya kaum Yahudi menuju cita-cita berdirinya negara Israel, sebagai tanah hidup mereka adalah; pertama; keyakinan mereka yang kuat 
pada Tuhan Esa Sang Maha Besar yang akan melindungi siapapun yang mematuhi perintahperintah-Nya sebagaimana tertuang dalam kitab Taurat. Faktor kedua adalah penciptaan identitas etnik yang menekankan keunggulan kaum Yahudi ditengah-tengah umat lainnya yang selalu berusaha menghancurkan mereka. Kedua faktor diatas memiliki sifat saling bertentangan. Alasannya; mereka percaya dan tunduk kepada Tuhan, tetapi malah menggunakan kalimat-kalimat Tuhan dalam kitab taurat yang mereka percayai sebagai landasan teologis untuk menegaskan identitas kulturalnya sekaligus merepresi umat lain.

Steve Olson (2003), dalam bukunya Maping Human History, telah melakukan penelitian mengenai genetika umat Yahudi. Menurutnya sejarah genetik kaum Yahudi berasal dari kromosom Y milik Aaron (Harun). Pertama-tama ia membangun tesanya berdasarkan Kitab Keluaran, Tuhan menitahkan bahwa saudara Musa, yaitu Aaron, dan seluruh keturunan lelakinya akan menjadi pendeta-pendeta tinggi Israel. Sampai sekarang, para lelaki keturunan langsung dari Aaron memiliki kedudukan-kedudukan istimewa di banyak Sinagog, seperti pemimpin -pemimpin pemberkatan tertentu. Dalam ajaran Yahudi secara keseluruhan, para lelaki ini disebut kohanim, kata dari bahsa Ibrani untuk menyebut pendeta. Disamping itu ada acuan menarik didasarkan pada kitab perjanjian lama yang menyatakan bahwa kakek moyang kaum Yahudi adalah dua belas anak lelaki Jacob (Ya'qub), yang keturunannya menempati wilayah-wilayah Kanaan setelah keluar dari Mesir. Selain itu, hukum agama Yahudi mewajibkan endogami kepada para pemeluknya - mengharuskan orang Yahudi menikah dengan orang Yahudi juga.

Kitab ulangan (Deuteronomy) 7;3 (http:// bible.ort.org) menyebutkan :

ולא תתחתן בם בתך לא־תתן לבנו ובתו לא־תקח לבנך: לאדת

"Furthermore, you shall not intermarry with them; you shall not give your daughters to their sons, nor shall you take their daughters for your sons.

Jika diartikan kurang lebih berbunyi:

"Janganlah engkau kawin-mengawini dengan mereka (orang-orang nonIsrael); anak-anakmu perempuan janganlah kau berikan kepada anak lelaki mereka, atau anak perempuan mereka janganlah kau ambil bagi anakmu laki-laki"

Dari keterangan diatas berarti jika peraturan ini dipatuhi sejak zaman Jakob, maka semua lelaki Yahudi akan memiliki kromosom Y. Jikapun benar, asumsi tersebut sudah tak relevan lagi sejak zaman kekinian bahkan berabad-abad sebelumnya. Umat Yahudi sudah tak lagi mempunyai ciri-ciri fisik yang spesifik menjadi kekhasannya (uniq). Mengapa demikian? sebab, semenjak masa diaspora, umat Yahudi telah berbaur dengan masyarakat lain, baik Eropa, Afrika, Asia, Amerika, dan lain-lain. Maka, lama- 
kelamaan perkawinan dengan orang-orang non -Yahudi, konversi orang-orang non-Yahudi ke dalam agama Yahudi tak terelakkan. Ini pertanda bahwa sifat-sifat biologis yang diklaim umat Yahudi sebagai bangsa unggul, terreduksi dengan sendirinya.

Struktur genetika umat yahudi diatas, terutama satu garis dengan keturunan Nabinabi, menjadi penguat klaim Yahudi sebagai the chosen people atau umat terpilih. Pada akhir abad ke 19 seiring dengan semakin kokohnya kekuatan Zionisme, wacana ini terus direproduksi sebagai narasi identitas yang diwariskan dari generasi ke generasi. Pada masa itu pula Theodor Herzl, seorang wartawan Yahudi asal Austria membuat propaganda menjadikan kaum Yahudi sebagai ras terpisah dari Eropa. Permisahan ini tak akan berhasil jika mereka masih hidup "serumah" dengan masyarakat Eropa. Sebab itu, membangun tanah air Yahudi menjadi sangat penting. Theodore Herzl, sang pendiri Zionisme mulanya memilih Uganda. Kemudian pilihan itu beralih menjadi Palestina oleh karena dianggap sebagai "tanah air kaum Yahudi" dan "tanah yang dijanjikan Tuhan". Inilah pangkal mula kenapa tanah Palestina terus dibanjiri darah dan air mata hingga saat ini. Sebagai propaganda massa, Zionis meniru propaganda anti-semitisme di Jerman. Ini bertujuan membangkitkan kesadaran rasial masyarakatnya.

Diserukan oleh tokoh-tokoh Zionis bahwa:

"ras orang-orang Arab lebih rendah dari Yahudi, Israel adalah sebuah negara kecil yang mencoba bertahan disuatu daerah yang dikelilingi oleh musuh-musuh, dan semua orang Palestina adalah teroris yang ingin menghancurkan Israel dan teroristeroris gila ini pantas menerima pembalasan dendam" (Yahya, 2003, 11).

\section{Etnisitas dan Budaya}

Keinginan kaum Yahudi untuk mendirikan negara sendiri, terlepas dari penindasan yang mereka alami dimanapun mereka berpijak, juga dipengaruhi oleh pengalaman sejarah nenek moyang mereka ditanah Arab. Hanya disanalah mereka menemukan makna identitas menyatu. Identitas yang terbangun melalui narasi bangsa dimana cerita, citra, simbol, dan ritual merepresentasikan makna "bersama" kebangsaan. Identitas nasional adalah identifikasi terhadap representasi pengalaman bersama dan sejarah yang dituturkan melalui berbagai kisah, sastra dan media. Narasi kebangsaan menekankan tradisi dan kontinuitas bangsa bersamaan dengan mitos dasar asal-usul kolektif. Pada gilirannya narasi kebangsaan mengasumsikan dan memproduksi keterkaitan antara identitas nasional dengan masyarakat murni, asli atau tradisi rakyat.

Bangsa Yahudi membangun narasi identitasnya salah satunya juga melalui pendekatan etnisitas dan budaya. Mereka selalu mempertahankan ikatan dengan kelompok-kelompok yang lebih menyerupai 
gerombolan dan suku daripada loyalitas pada negara. Kelompok-kelompok ini secara khusus disatukan oleh simbol-simbol atau atributatribut kultural tertentu seperti bahasa dan kampung halaman yang sama. Anggota kelompok ini selalu mengklaim mempunyai asal-usul biologis yang sama. Artinya; ikatan etnik ini lebih didasarkan pada kesamaan budaya terlepas apakah mereka mempunyai ikatan satu sama lain.

Untuk itu umat Yahudi terus mereproduksi etnisitas mereka melalui narasi, mitos yang diceritakan turun temurun mengenai sejarah kebangsaan kaum Yahudi. Diceritakanlah terus menerus tentang Yahudi sebagai umat pilihan, bangsa unggul, keturunan suci langsung dari garis keturunan nabi-nabi, memiliki tanah yang dijanjikan Tuhan, dan sebagainya. Secara langsung ia akan mempengaruhi kesadaran etnisitas pada setiap kelompok masyarakatnya, walaupun sebenarnya mereka tak mempunyai ikatan apa-apa. Inilah yang menurut saya meneguhkan kesatuan umat Yahudi dalam upaya mereka mendirikan negara merdeka, yang sekarang telah eksis, yaitu Israel. Dikemudian hari, narasi etnisitas ini akan memunculkan semangat primordial bagi masing-masing kelompok masyarakat dan rentan akan gesekan dengan kelompok masyarakat lain. Ada kecenderungan untuk memandang orang lain sebagai pihak lain yang berbeda bukan hanya secara kultural tetapi juga genetik.

Jadi ras maupun etnisitas secara erat telah dikaitkan dengan nasionalisme yang mengonsepsikan bangsa sebagai suatu kebudayaan yang dimiliki bersama yang mensyaratkan agar sekat-sekat etnis tidak bersinggungan dengan batas-batas politis, konsep ideal tentu saja, namun tidak dapat diterapkan ansich begitu saja. Negara bangsa adalah konsep politis yang mengacu pada aparat administratif yang dipercaya mempunyai kedaulatan atas kawasan atau wilayah tertentu dalam sistem negara bangsa. Dan inilah pengejawantahan mendasar dari masalah utama kajian tulisan ini. Identitas nasional adalah bentuk identifikasi imajinatif terhadap simbol dan diskursus negara-bangsa. Jadi, bangsa bukan hanya sekedar bangunan politis melainkan sistem representasi budaya dimana identitas nasional terus menerus direproduksi sebagai tindakan diskursif. Negara bangsa sebagai aparatur politik dan bentuk simbolis mengandung dimensi temporer dimana struktur politik melanggengkan dan mengubah ketika dimensi simbolis dan diskursif identitas nasional mengisahkan dan menciptakan gagasan tentang asal-usul, kontinuitas dan tradisi. Dalam hal ini tentu kita dapat melihat kedalaman akar sejarah kenapa bangsa Yahudi begitu ngotot untuk mendirikan negara sendiri sebagai pengejawantahan identitas kulturalnya.

Etnisitas adalah konsep budaya yang terpusat pada kesamaan norma, nilai, kepercayaan, simbol dan praktik budaya. Terbentuknya suku bangsa bersandar pada penanda budaya yang dimiliki secara bersama yang telah berkembang dalam konteks historis, 
sosial dan politis tertentu dan yang mendorong rasa memiliki yang, paling tidak, sebagian didasarkan pada nenek moyang mitologis yang sama. Artinya etnisitas dibentuk oleh cara kita berbicara tentang identitas kelompok dan mengidentifikasikan diri dengan tanda dan simbol yang membangun etnisitas.

\section{Agama}

Proses reproduksi identitas keyahudian menuju berdirinya negara Israel, juga berangkat atas dasar dalil-dalil agama, terutama Taurat. Pertama, narasi tentang umat pilihan. Bangsa Yahudi mereproduksi narasi identitas tentang umat pilihan didasarkan pada teks-teks kanonik. Yang menjadi acuan utama adalah teks-teks Taurat. Berikut ini teks Taurat dalam buku Genesis 14;2 (http://bible.ort.org)

$\mathrm{Ki}$ am kadosh atah l'Adonay Eloheycha uvecha bachar Adonay lihyot lo le'am sgulah mikol ha'amim asher al-peney ha'damah.

You are nation consecrated to God your Lord. God has chosen you from all nation on the face of the earth to be his own special nation.

Dan Taurat buku Exodus 19;5 (http:// bible.ort.org)

Ve'atah im-shamoa tishme'u bekuliushmartem et-britiviheyitem li sgulah mikol-ha'amim ki-li kol-ha'arets

Now if you obey Me and keep My covenant, you shall be My special treasure among all nations, even though all the world is mine
Dan Taurat buku Deutoronomy 7;7 (http:// bible.ort.org)

Lo merubechem mikol-ha'amim chashak Adonay bachem vayivchar bachem kiatem hame'at mikol-ha'amim.

It was not because you had greater numbers than all the nations that God embraced You and Chose you, you are among the smallest of all the nation

Kedua, Yahudi sebagai keturunan nabinabi. Secara historis, mereka mengklaim bahwa bangsa Yahudi adalah penerus dari dua belas suku keturunan Yehuda yang mengacu kepada Abram (Abraham) dari garis Isaac.

Ketiga, klaim atas tanah terjanji (promised land). Ini juga mengacu pada teks Taurat buku Deuteronomy 7;8 (http:// bible.ort.org)

Ki me'ahavat Adonay etchem umishomro et-hasvu'ah asher nishba la'avoteychem hotsi Adonay etchem beyad chazakah vayidecha mibeyt avadim miyad par'oh melechMitsrayim.

It was because of God's love for you, and because He was keeping the oath that He made to your fathers. God therefore brought you out with a mighty hand, liberating you from the slave house, (and) from the power of pharaoh king of Egypt.

Dan Taurat buku Deuteronomy 19;8 (http:// bible.ort.org)

Ve'im-yarchiv Adonay Eloheycha et- 
Elpeni Fitrah

gvulecha ka'asher nishba la'avoteycha venatan lecha et-kol-ha'arets asher diber latet la'avoteycha.

God will (eventually) expand your borders, as He swore to your fathers, and He will give you all the territory that he promised them. 
Selanjutnya Deuteronomy 1;7 dan 1;8: (http://bible.ort.org)

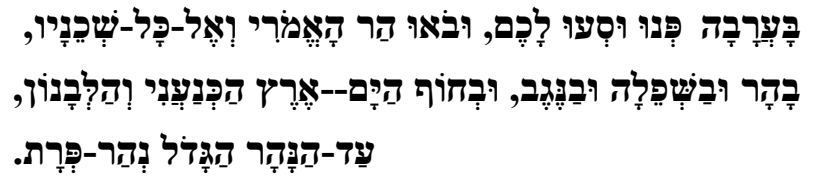

( turn you, and take your journey, and go to the hill-country of the Amorites and unto all the places nigh thereunto, in the Arabah, in the hill-country, and in the Lowland, and in the South, and by the seashore; the land of the Canaanites, and Lebanon, as far as the great river, the river Euphrates)

Dan,

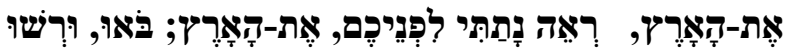

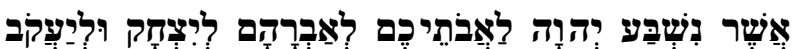

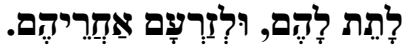

\begin{abstract}
( Behold, I have set the land before you: go in and possess the land which the LORD swore unto your fathers, to Abraham, to Isaac, and to Jacob, to give unto them and to their seed after them.)
\end{abstract}

Saat mereka diperlakukan kejam oleh Raja Mesir Fir'aun, Musa berseru pada kaumnya untuk meninggalkan Mesir. Sekitar tahun $1250 \mathrm{SM}$, mereka tinggal di Semenanjung Sinai dan timur Kanaan. Sebagaimana Taurat diatas; umat Yahudi mengidentifikasi Palestina sebagai "tanah yang terjanjikan". Tanah itu harus direbut kembali, dan dibangun sebuah negara merdeka demi cita-cita nasional umat Yahudi.

Bangsa Yahudi mengalami diaspora sejak dibuang oleh raja Babilonia, Nebuchadnezzar pada abad ke enam Sebelum Masehi. Walaupun diizinkan kembali oleh raja Persia Kyros pada tahun 539 SM, namun sebagian memilih meninggalkan kampung halaman untuk mencari penghidupan baru. Tanah Eropa menjadi tujuan yang paling diminati. Namun kehidupan mereka tidaklah semulus yang diharapkan. Bangsa mereka diklaim oleh gereja kristen Eropa sebagai pemberontak terhadap "agama sejati", yang bertanggung jawab atas kematian Kristus dan secara umum dianggap sebagai wujud kejahatan.

Agama, walau sifatnya ghaib, telah menjadi pegangan manusia sejak manusia itu ada. Agama atau kepercayaan terhadap Tuhan atau sesuatu yang transenden, Ilahi, dan Yang Maha Kuasa dianggap sebagai hal yang natural akibat keterbatasan manusia dalam menghadapi realitas dan kejadian-kejadian alam serta realitas psikologis manusia yang kenyataannya lemah dan terbatas. Menurut Isaac, agama merupakan suatu ikatan terhadap tradisi warisan yang berasal dari kearifan kuno dan ajaran-ajaran yang dikumpulkan sepanjang waktu yang ditularkan secara lisan maupun tulisan, disampaikan, dibaca serta diterjemahkan berulang-ulang oleh pewaris pemeluk berikutnya (Abdillah, 2003, 67).

Karena kekuatan agama dalam mengikat individu dalam suatu kebersamaan 
yang sangat kuat, agama menjadi komoditas politik yang kental bagi beberapa kelompok individu. Kita melihat dalam konstelasi politik sebuah negara (yang nampak jelas tentu Indonesia), banyak partai-partai politik yang menjadikan agama sebagai asas politiknya. Sebelum muncul fajar pencerahan, tonggak baru peradaban modern, gereja waktu itu adalah lembaga kekuasaan tertinggi paling ditakuti. Agama memegang kendali aturanaturan kehidupan, agama bahkan mengambil peran kekuasaan sampai pada tingkat masalah pribadi. Kondisi ini yang dirasakan selama abad pertengahan (middle age) yang dianggap memasung kreativitas dan kemerdekaan oleh sebab doktrin-doktirin religi yang ketat.

Dibelahan negara lain, konstitusi dan sistem politiknya diyakinkan pada agama tertentu dengan keyakinan bahwa agama (normativitasnya) meliputi seluruh aspek kehidupan manusia. Agama islam yang bagi pemeluknya merupakan satu kesatuan sistem telah mendeterminasi adanya negara Islam. Keterikatan pada masing-masing normativitas doktrinal menempatkan kelompok-kelompok poltik agama pada posisi yang determinan. Pada posisi ini, seringkali konfrontasi politik agama tak bisa dihindarkan.

Agama-agama berkonfrontasi antara satu dengan yang lain sebagai satu kepercayaan, sebagai lembaga dan sebagai perwakilan dari pengaruh-pengaruh yang bersaing. Pertempuran dan perjuangan yang dilakukan diantara mereka itu sebagian besar merupakan bagian dari politik semata, secara eksplisit maupun tersamar. Misalnya konflik antara Israel dan Palestina. Ia tidak hanya menjadi bentuk perjuangan mempertahankan tanah wilayahnya melainkan telah bertranformasi menjadi pertikaian antar iman. Israel menggunakan doktrin-doktrin ke-Yahudi -annya untuk memobilisasi massa, seperti Palestina sesuai ajaran Musa adalah "tanah yang dijanjikan" makanya harus direbut oleh kaum Yahudi. Sedangkan Palestina dan negara Timur Tengah, menggunakan doktrin Islam untuk menggerakkan Masyarakat. seperti konsep Jihad dan sebagainya.

Donny Gahral Ardian (2005) mengatakan bahwa wacana pinggiran dalam politik beragama muncul dalam gerakan spiritualisme, sinkretisme, fundamentalisme, ekletisisme, sufisme dan gerakan-gerakan spiritual non-lembaga keagamaan. Ia nampaknya agak terpengaruh oleh konsepsi Marx, tentang agama. Marx menyebutkan bahwa "agama adalah candu masyarakat" karena melihat struktur agama dalam masyarakat. Wacana (Marxis) muncul dari kritisisme terhadap bentuk-bentuk pelembagaan terhadap agama, agama yang hanya dipahami dan dipraktikkan sebagai suatu instuisi kepercayaan sampai menjadikannya sebagai intuisi politik dan ideologi. Padahal, agama, dalam sejatinya adalah salah satu cara pemenuhan kebutuhan dasariah manusia, kebutuhan batin dan spiritual. Dengan demikian, ketika agama-agama yang ada tidak memenuhi harapan kebutuhan tersebut, muncullah agama-agama baru agama yang bukan hanya sekedar identitas formal. 


\section{Kesimpulan}

Dalam kajian budaya, identitas dipandang bersifat kultural dan tidak punya keberadaan di luar representasinya dalam wacana kultural. Identitas bukan sesuatu yang tetap yang bisa kita simpan, melainkan suatu proses menjadi. Etnisitas, ras dan nasionalitas adalah konstruksi-konstruksi diskursifperformatif yang tidak mengacu pada 'bendabenda' yang sudah ada. Artinya, etnisitas, ras dan nasionalitas merupakan kategori-kategori kultural yang kontingen dan bukan 'fakta' biologis yang universal. Sebagai konsep, etnisitas mengacu pada pembentukan dan pelanggengan batas-batas kultural dan punya keunggulan dalam penekanannya pada sejarah, budaya dan bahasa.

Ras adalah sebuah gagasan yang problematis karena asosiasinya dengan wacana biologis tentang superioritas dan subordinasi yang intrinsik dan tak terhindarkan. Meski demikian, konsep rasialisasi atau pembentukan ras punya kegunaan karena menekankan pada kekuasaan, kontrol dan dominasi. Ide tentang identitas, ras, etnisitas dan bangsa mesti dilihat dalam kerangka saling bersandarnya yang satu pada lainnya, seperti dalam hal kemurnian etnis suatu bangsa yang dihipotesiskan oleh wacana nasionalisme.

Indikasi pemanfaatan narasi identitas dibalik berdirinya negara Israel hampir pasti mengarah pada argumen diatas. Umat Yahudi diaspora yang sejak lama merindukan tanah air sendiri berhasil mendirikan negara bangsa di tanah historis mereka, "tanah yang terjanjikan" untuk "orang-orang yang terpilih", setidaknya demikian Musa dulu bersabda pada mereka. Politik identitas menjadi alat utama bagi Yahudi-Zionis untuk mewujudkan cita-cita tersebut. isu-isu yang dibawa antara lain ras, budaya dan agama.

Dalam pendekatan teori persepsi disebutkan bahwa Persepsi adalah pandangan seseorang yang telah melalui tahapan melihat, merasa, memikirkan dan diolah oleh pengalaman dan teori yang diyakini. Hasil persepsi ini akan berpengaruh terhadap pembuatan keputusan sekaligus bentuk prilaku kelompok tersebut secara keseluruhan. "Perception can have a huge impact on decision-making and on an organization's behavior in whole."demikian ucap Robbins. Persepsi-persepsi tersebut kadangkala memudarkan kenyataan dan salah penafsiran sehingga sering kali menjurus kepada konflik brutal. Ketika disandingkan dengan realitas memang begitulah yang terjadi. Keputusan Yahudi mendirikan negara Israel di tanah Palestina, menimbulkan konflik berkepanjangan. Oleh sebab itulah saya sebutkan ada potensi negatif yang tercipta ketika kelompok masyarakat berjuang atas nama identitasnya. Pemisahan diri dalam rangka membentuk negara merdeka sendiri dengan menarasikan berdasarkan ikatan identitas yang lebih spesifik seperti, budaya, agama dan etnis tertentu adalah keinginan paling mendasar manusia, tuntutan untuk memperolah pengakuan (desire for recognition). 


\section{Daftar Pustaka}

Abdillah, Ubed. Politik Identitas Etnis; Pergulatan Tanda Tanpa Identitas. Indonesiatera. 2002.

Hardiman, F. Budi. Menuju Masyarakat Komunikatif; Ilmu, Masyarakat, Politik, dan Postmodernisme Menurut Jurgen Habermas. Yogyakarta; Kanisius. 2003.

Horowitz, Donald L. Ethnic Groups in Conflict. Berkeley: University of California. 1985.

Lee, Robert D. Diterjemahkan oleh Ahmad Baiquni. Mencari Islam Outentik dari Nalar Puitis Iqbal hingga Nalar Kritis Arkoun. Bandung: Mizan. 2000.

Madison, G.B. The Hermeneutics of Postmodernity: Figures and Themes. Bloomington and Indianapolis: Indiana University Press. 1988.

Mas'oed, Mochtar dan Collin M. Andrew. Perbandingan Sistem Politik. Yogyakarta. Gajah Mada University Press. 2000.

Ricoeur, Paul. Hermeneutika Ilmu Sosial. Yogyakarta; Kreasi Wacana. 2006

Valdes, M.J. Phenomenological Hermeneutical Hermeneutics and the Study of Literature. London: University of Toronto Press. 1987.

Yahya, Harun. Palestina Zionisme dan Terorrisme Israel. Bandung: Dzikra. 2005.

Sumber Internet; 
Anak Agung Banyu Perwita, Ph.D. Keamanan Non-Tradisional dan Desain Baru Politik Luar Negeri Indonesia. Diakses dari: http://www.unpar.ac.id/newsdtl.asp?rnd=2006J4FCqWVH1WwDT\&id=2 006AHFRJVQCaPEUg

Dony Gahral Ardian. Politik Identitas, Teologi dan Satanisasi Musuh. http://www.serambi.co.id/modules.php?name=Gagas\&aksi=selanjutnya\&ID

Fredrick Toben: Negara Israel Dibangun di Atas Kebohongan. http://www.eramuslim.com

Hermeneutik, Tawaran yang Menggiyurkan, diakses dari

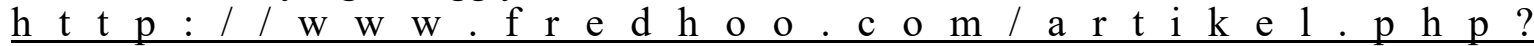
subaction $=$ showfull\&id $=1164158380 \&$ archive $=\&$ start from $=\& u c a t=3 \&$

Lapadi, Saleh. Hermeneutika Punya Banyak Kamar. Diakses dari: http://www.al-shia.com/html/id/service/maqalat/013.htm

Mujib, M. Khairul. Hermeneutika Romantis-Historis Dilthey. Diakses dari; www.daunlontar.com

Philips J. Vermonte dan Irine H. Gayatr. Conflict Entrepreneur: Konsep dan Utilisasinya dalam memahami konflik di Ambon, http://interseksi.org. 